\title{
The Effect of Electronic Banking on Bank Performance in Nigeria
}

\author{
Amos Olushola Michael $^{1 *} \quad$ Umar Halidu Ahmad (PhD) $^{1} \quad$ Busari Adekunle Hakeem $^{1}$ \\ Ekpe Mary-Jane $^{2} \quad$ Kolawole Babajide ${ }^{2}$ \\ 1.Department of Banking and Finance, School of Business Studies, Federal Polytechnic Nasarawa, Nigeria \\ 2.Department of Accountancy, School of Business Studies, Federal Polytechnic Nasarawa, Nigeria
}

\begin{abstract}
This study ascertains the effect of electronic banking on bank performance in Nigeria. The study utilized secondary data derived from the audited annual financial statement of the deposit money banks quoted on the Nigerian Stock Exchange from 2008-2017. The study also made use of journals, textbooks, Nigerian Stock Exchange fact books, the Central Bank of Nigeria (CBN) Bullions and other published materials. Using the multiple regression analysis techniques, the findings revealed that e-banking measured by return on equity (ROE), return on assets (ROA), and earnings per share (EPS) has no significant impact on the performance of banks in Nigeria. With the findings, we can conclude that investment in electronic banking has not improved the performance of deposit money banks in Nigeria. The study recommends that for effectiveness in electronic banking, there should be rigorous campaign and awareness for clients to patronise the facilities.
\end{abstract}

Keywords: Electronic Banking, Bank Performance, Deposit Money Bank, Nigerian Stock Exchange, CBN, ICT DOI: $10.7176 / \mathrm{EJBM} / 12-26-09$

Publication date:September $30^{\text {th }} 2020$

\section{Introduction}

Nigerian banks have moved away from a manual system to an automated method of banking. Major tasks in banking operations today are being handled by an electronic system such as retrieval, storage and processing of information. Banks in Nigeria are constantly involved in all forms of information management irrespective of whether they are automated or not (Ovia, 2001). The art of a customer performing banking transactions electronically without physically paying a visit to any financial institution is known as electronic banking. It is the electronic delivery of banking products and services directly to customers wherever they are and could either be in form of internet banking, virtual banking, online banking, personal computer (PC), home banking, remote ebanking or phone banking. The most frequently used designations are the personal computer (PC) banking and the internet or online banking. Several terminologies are being used to describe e-banking and are often used interchangeably (Taylor and Todd, 1995). The banking sector in Nigerian has witnessed several regulatory and institutional reforms which are primarily meant to raise the standard and performance of the sector. In 2004, the Central Bank of Nigeria (CBN) initiated a reform that has to do with consolidation and recapitalization of the banking sector in Nigeria primarily to reduce the number of deposit money banks in the system and to make the emerging banks stronger, reliable and to be able to compete internationally. Before this, there were massive challenges in the banking sector such as fraudulent practices and corruption, erosion of public confidence, low asset quality, low capital base, repeated cases of failures, distress, etc. ( Auta, 2010).

Banks in Nigeria have vehemently adopted electronic and communication networks for service delivery and value-added products in an attempt to meet up with international standards, global developments and quality service delivery. In the recent past, banks in Nigeria have upgraded from manual to electronic systems, thereby replacing the old ledger card system with the computer networks, to facilitate the act of branch-banking and interbanking transactions.

There have been shreds of evidence on the adoption of e-banking in the last few years which has led to remarkable success in value-added product and service delivery in the Nigerian banking sector. (Agboola, 2006; Ayo, 2010). Idowu, Alu and Adagunodo (2002), observed that the use of technology in banking operations in Nigerian banks will make them have an edge over their competitors. This has led to substantial growth in the adoption of e-banking operations in the Nigerian banking industry (Salawu \& Salawu, 2007). The introduction of electronic devices in banking operations in the Nigerian banking industry has helped to increase effectiveness, efficiency and healthy competition. This has to a reasonable extent, helped to reduce long queues in the banking hall and customers' waiting time in carrying out transactions. Dandapani (2006), reiterated that the adoption and the acceptance of e-banking in the Nigerian banking industry do not in any way mark an improvement in the performance of banks neither the apparent use of the delivery mechanisms makes it more profitable, economically viable or fruitful in all aspect.

The financial performance of an organization is essential for its survival both in the short and in the long run. There is a debate as to whether the adoption of e-banking has improved the performance of banks in Nigeria despite the benefits derived from e-commerce and ICT. To reap the potential benefits of investment in ICT, there must be training and retraining of personnel that will handle the various operations to acquire the necessary skills required 
(Rogers, 1995). For a country to maintain financial stability, economic growth and development, there must be a strong banking system. Consequently, the revolution in the information and communication technology has given banks the motivation to spend more on technology to attract more customers and to maximize returns. Besides, there is a change in the operations of banks since the adoption of e-banking (Salhi and Alipour, 2010).

\subsection{Statement of the Problem}

There is a paradigm shift in Nigerian banking operations since the adoption of information and communication technology (ICT) in the banking sector of the economy. The adoption has brought about improvement and effectiveness in service delivery. Consequently, banks in Nigeria especially deposit money banks have seen electronic banking not just as an innovative payment method but as a means of increasing the number of customers, patronage and also a way of cutting operating cost to enhance profitability.

Banks in Nigeria have been forced to find new and profitable areas to explore due to the fierce competition among them. However, online banking appears to be a better option for new entrants in the banking sector.

Presently, the deposit money banks in Nigeria have all adopted e-banking to the fullest in carrying out major banking operations. This has helped to compete favourably, respond promptly to changes and meet up with the acceptable global standard. Also, it has helped in meeting the needs of customers in terms of low transaction cost and reduction in waiting time.

The adoption and the acceptance of e-banking in the Nigerian banking industry do not in any way mark an improvement in the performance of banks neither the apparent use of the delivery mechanisms makes it more profitable, economically viable or fruitful in all aspects, bringing about a state of a dilemma on the effect of ebanking on the performance of banks in Nigeria. It is pertinent therefore for bankers, regulatory and supervisory agencies and researchers to know how e-banking affects the performance of banks in Nigeria. To this end, the researchers' primary objective is to fill this notable gap by providing a well-structured investigation on "the impact of electronic banking services on the performance of banks in Nigeria."

\subsection{Objectives of the Study}

The primary goal of this research work is to ascertain the effect of electronic banking on bank performance in Nigeria. The specific objectives include;

1. To determine the impact of electronic banking on return on asset

2 . To ascertain the effect of electronic banking on return on equity.

3. To assess the impact of electronic banking on earnings per share

\subsection{Research Hypotheses}

The following hypotheses formulated in their null form will be tested:

$\mathrm{Ho}_{1}$ : Electronic banking has no significant effect on the return on asset

$\mathrm{Ho}_{2}$ : Electronic banking has no significant impact on the return on equity

$\mathrm{Ho}_{3}$ : Electronic banking has no significant effect on earnings per share.

\section{Empirical Review}

E-banking being a current trend in the banking industry, many scholars have examined the subject matter from a different perspective. For example, an investigation carried out by Oginni, Mohammed, El-Maude and Arikpo (2013) on the impact of e-banking on bank performance in Nigeria using macroeconomic control variables revealed that e-banking has a positive influence on the performance of banks in Nigeria. The study adopted a ten year annual audited financial statements of selected deposited money banks using the ordinary least square regression analysis on the relationship between e-banking on return on asset, return on equity and net interest margin.

Following the adoption of e-banking in Nigeria, Abaenewe, Ogbulu and Ndugbu (2013) investigated the profitability performance of Nigerian banks using a standard statistical technique to measure the profitability of ebanking in terms of return on assets and return on equity. The results show that there is no significant improvement in return on asset following the adoption of e-banking while on the contrary; it shows that e-banking has a positive significant improvement in return on equity.

E-banking has a strong and significant effect on return on assets as seen in the work of Josiah and Kingoo (2012) on the relationship between performance and the adoption of e-banking in Kenya banking system using both the inferential and descriptive statistical analysis to analyze the data.

Mohammad and Saad (2011) examined the impact of electronic banking on bank performance in Jordan using 15 banks from the year 2000-2010. The ordinary least square (OLS) regression results revealed that electronic banking does not impact positively on bank performance.

Malhotra and Singh (2009) accessed the impact of internet banking on the Indian banking industry based on the data from 85 commercial banks' websites, during June 2007. The results of the multiple linear regression 
models revealed that internet banking services and profitability do not have any significant relationship.

\section{Methodology \\ 3.1 Introduction}

This section presents the method adopted in this study. The area spells out the research design, which makes it possible for the researchers to draw inferences from the data analyzed in terms of generalization. Precisely, this section sets out the method used for testing the research hypotheses derived from the research questions.

\subsection{Research Design}

This study utilizes a correlation survey design. It attempts to correlate the impact of electronic banking on the performance of bank in Nigeria using three widely used proxies, i.e. return on assets (ROA), return on equity (ROE) and earnings per share (EPS) for measuring bank performance. Besides, the various e-banking services provided by banks in Nigeria such as Internet Banking, ATM, Point of Sale and Mobile Banking are used for measuring e-banking

\subsection{Study Population}

The population includes all the Deposit Money Banks in Nigeria as of 2017. The time frame considered for this study is from 2008 to 2017.

\subsection{Sample Size}

Sampling entails choosing a few from a given population. The sample size includes all the 21 deposit money banks in Nigeria from 2008-2017 listed on the Nigerian Stock Exchange and retains their brand name.

\subsection{Sources of Data}

The audited financial statements of deposit money banks quoted on the Nigerian Stock Exchange (NSE) for the period under review were utilized. Besides, the study made use of the Nigerian Stock Exchange Fact Book and the Central Bank of Nigeria bulletin

\subsection{Variables Measurement}

\subsubsection{Dependent Variables}

Looking critically at the study, the dependent variable is bank performance measured by return on assets, return on equity and earnings per share.

Return on Equity (ROE): Return on equity reflects how effectively the management of banks uses shareholders' fund. It shows how profitable the owner's investment is. It is given as:

$$
\begin{gathered}
\mathrm{ROE}= \\
\text { Total Equity capital }
\end{gathered}
$$

Returns on Assets (ROA): This is the ratio of income to total assets. It measures the ability of the bank's management to generate revenue by utilizing bank assets at their disposal. It also shows the efficient use of the resources of the company in creating income. The formula is given as:

$$
\text { ROA }=\frac{\text { Net profit after tax }}{\text { Total Assets }}
$$

Earnings per Share (EPS): This ratio indicates the amount of profit earned on each outstanding ordinary share, usually expressed in kobo. It is given as:

\section{EPS $=$ Net profit after tax} Number of Shares

\subsubsection{Independent Variables}

The independent variable is Electronic Banking (EB) measured by the various e-banking services offered by the banks in Nigeria. These services include ATM, PoS, Web (Internet) and Mobile Banking. The apriori expectation is a positive sign for these variables as e-banking is capable of reducing operating cost.

\subsection{Model Specification}

The modified version of the econometric model of Miyajima was adopted for this study. The model used in testing the hypotheses of this study is given as:

Perf $=\alpha+\beta_{1} X_{1}+\beta_{2} X_{2}+\beta_{3} X_{3}+\beta_{4} X_{4}+e$

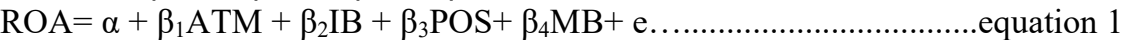

$\mathrm{ROE}=\alpha+\beta_{1} \mathrm{ATM}+\beta_{2} \mathrm{IB}+\beta_{3} \mathrm{POS}+\beta_{4} \mathrm{MB}+\mathrm{e} \ldots \ldots \ldots \ldots \ldots \ldots \ldots \ldots \ldots$. equation 2

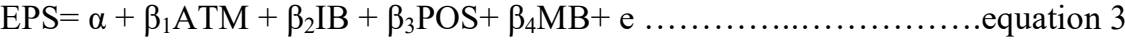

Where: 
Perf $=$ Bank Performance

$\mathrm{ATM}=$ Automated Teller Machine as an independent variable

IB $=$ Internet Banking

POS $=$ Point of Sales

$\mathrm{MB}=$ Mobile Banking

ROA $=$ Return on Asset

$\mathrm{ROE}=$ Return on Equity

EPS $=$ Earnings per Share

$\alpha=$ Constant

$\beta_{1}-\beta_{4}=$ Coefficient of the independent variable

\subsection{Data Analysis Techniques}

The data collected determines the type of tool to be adopted for analysis. This study uses multiple regression techniques as a tool of analysis. ROA also measures electronic banking which is the independent variable and bank performance which is the dependent variable, ROE and EPS of Nigerian deposit money banks listed on the Nigerian Stock Exchange (NSE), as at December 31, 2017. Therefore, the study has four independent variables and one dependent variable.

\section{Data Presentation, Analysis and Results}

This section covers the presentation and the analysis of the data collected from the selected banks in the course of the research work. The hypotheses formulated are tested in this section to discover the association between the variable. The aim is to find out whether electronic banking has an impact on bank performance in Nigeria.

\subsection{Data Presentation}

Table 1: Aggregate Value of Dependent and Independent Variables Computed from the Nigerian Stock Exchange Fact Book 2018

\begin{tabular}{|l|l|l|l|l|l|l|l|}
\hline \multicolumn{3}{|l}{ Dependent Variable } & \multicolumn{2}{l|}{ Independent Variables } \\
\hline YEARS & ROA & ROE & EPS & ATM & INTERNET & POS & MOBILE \\
\hline 2008 & 2.85 & 3.11 & 0.26 & 4.3 & 0.04 & 0.2 & 0.01 \\
\hline 2009 & 1.58 & 1.47 & 0.23 & 7.8 & 0.13 & 0.6 & 0.03 \\
\hline 2010 & 0.85 & 0.10 & 0.07 & 12.1 & 0.2 & 0.8 & 0.04 \\
\hline 2011 & 0.34 & 0.07 & 0.005 & 15.7 & 0.9 & 0.4 & 0.7 \\
\hline 2012 & 0.04 & 0.11 & 0.01 & 60.1 & 1.6 & 1.2 & 3.2 \\
\hline 2013 & 1.58 & 0.50 & 0.09 & 109.6 & 2.7 & 0.9 & 1.8 \\
\hline 2014 & 0.06 & 0.03 & 0.009 & 186.2 & 7.2 & 1.1 & 1.2 \\
\hline 2015 & 0.09 & 0.09 & 0.011 & 347.6 & 3.4 & 2.1 & 1.9 \\
\hline 2016 & 0.25 & 0.19 & 0.03 & 375.5 & 2.3 & 2.6 & 1.5 \\
\hline 2017 & 4.87 & 1.72 & 0.15 & 295 & & Author's.4 & 15.8 \\
\hline
\end{tabular}

Source: Author's Computation from the Nigerian Stock Exchange Fact Book 2018

\subsection{Data Analysis}

As stated earlier, a test was carried out on the three specific hypotheses to determine the effect of electronic banking on the various banks' performance indicators studied in this research work which include ROA, ROE and EPS. The regression results are shown below:

\subsection{Test of Hypotheses}

4.3.1 Ho1: Electronic banking has no significant effect on the return on asset.

Table 2: Regression Result Computation from Table 1 above

\begin{tabular}{|c|c|c|c|c|c|}
\hline \multirow[b]{2}{*}{ Model } & \multicolumn{2}{|c|}{ Unstandardized Coefficients } & \multirow{2}{*}{$\frac{\text { Standardized Coefficients }}{\text { Beta }}$} & \multirow[b]{2}{*}{$\mathrm{T}$} & \multirow[b]{2}{*}{ Sig. } \\
\hline & $\mathrm{B}$ & Std. Error & & & \\
\hline $1 \quad$ (Constant) & 1.045 & .574 & & 1.820 & .128 \\
\hline ATM & -.007 & .006 & -.627 & -1.193 & -287 \\
\hline INTERNET & -.072 & .237 & -.100 & -.305 & .773 \\
\hline POS & .880 & .959 & 1.531 & .918 & .401 \\
\hline MOBILE & -.155 & .492 & -.469 & -.315 & .765 \\
\hline
\end{tabular}

Dependent Variable: ROA

Source: SPSS Printout of Multiple Regression Computed from table 1 above 
Table 3: Model Summary

\begin{tabular}{|c|c|c|c|c|c|c|c|}
\hline \multirow[b]{2}{*}{ Model } & \multirow[b]{2}{*}{$\mathrm{R}$} & \multirow[b]{2}{*}{$\begin{array}{c}\mathrm{R} \\
\text { Square }\end{array}$} & \multirow[b]{2}{*}{$\begin{array}{l}\text { Adjusted R } \\
\text { Square }\end{array}$} & \multirow[b]{2}{*}{$\begin{array}{l}\text { Std. Error of the } \\
\text { Estimate }\end{array}$} & $\begin{array}{l}\text { Durbin- } \\
\text { Watson }\end{array}$ & & \\
\hline & & & & & $\begin{array}{l}\text { R Square } \\
\text { Change }\end{array}$ & $\begin{array}{c}\mathrm{F} \\
\text { Change }\end{array}$ & $\begin{array}{l}\text { Durbin } \\
\text { Watson }\end{array}$ \\
\hline 1 & $.852^{\mathrm{a}}$ & .725 & .505 & 1.10225 & .725 & 3.297 & 1.390 \\
\hline
\end{tabular}

Source: SPSS Printout of Multiple Regression Computed from table 1 above

Table 4: ANOVA

\begin{tabular}{|l|l|l|l|l|l|}
\hline Model & Sum of Squares & Df & Mean Square & F & Sig \\
\hline Regression & 16.021 & 4 & 4.005 & 3.297 & .111 \\
Residual & 6.075 & 5 & 1.215 & & \\
Total & 22.096 & 9 & & & \\
\hline
\end{tabular}

Source: SPSS Printout of Multiple Regression Computed from table 1 above

The tested hypothesis and the regression result in table 2 reveal that coefficient of POS is 1.531 , which indicate a positive relationship between ROA and POS. However, coefficient of ATM, INTERNET and MOBILE Banking are $-0.627,-0.100$ and -0.469 , showing that ROA and ATM, INTERNET and MOBILE Banking are negatively correlated. If the p-value $<5 \%$, the correlation is confirmed at $95 \%$ confidence level and otherwise is rejected. Therefore $p$-value of $0.287,0.773,0.401$ and 0.765 are more abundant than 0.05 significant levels which indicate that it is not statistically significant. By this, we accept the null hypothesis by rejecting the alternative idea and conclude that return on assets is not significantly influenced by electronic banking.

4.3.2 Ho2: Electronic banking has no significant impact on bank returns on equity

Table 5: Regression Result Computation from Table 1 above

\begin{tabular}{|c|c|c|c|c|c|}
\hline \multirow[b]{2}{*}{ Model } & \multicolumn{2}{|c|}{ Unstandardized Coefficients } & $\begin{array}{c}\text { Standardized } \\
\text { Coefficients }\end{array}$ & \multirow[b]{2}{*}{$\mathrm{T}$} & \multirow[b]{2}{*}{ Sig. } \\
\hline & $\mathrm{B}$ & Std. Error & Beta & & \\
\hline $1 \quad$ (Constant) & 1.146 & .523 & & 2.192 & .080 \\
\hline ATM & -.006 & .005 & -.818 & -1.108 & .318 \\
\hline INTERNET & -.099 & .216 & -.212 & -.461 & .664 \\
\hline POS & .799 & .873 & 2.148 & .916 & .402 \\
\hline MOBILE & -.324 & .448 & -1.515 & -.724 & .502 \\
\hline
\end{tabular}

Dependent Variable: ROE

Source: SPSS Printout of Multiple Regression Computed from table 1 above

Table 6: Model Summary

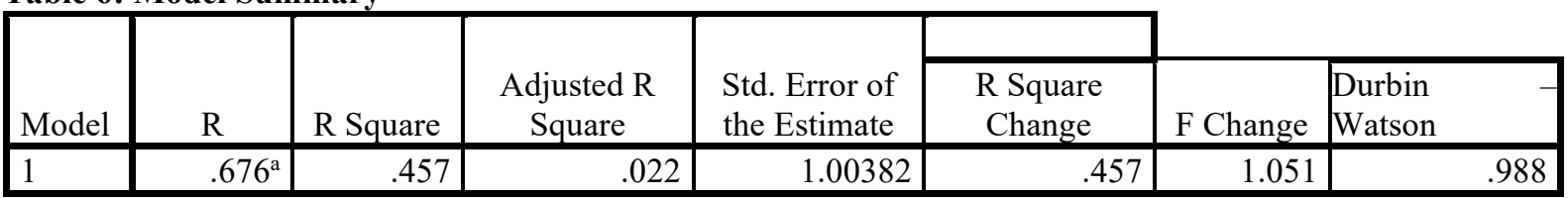

Source: SPSS Printout of Multiple Regression Computed from table 1 above

Table 7: ANOVA

\begin{tabular}{|l|l|l|l|l|l|}
\hline Model & Sum of Squares & Df & Mean Square & F & Sig \\
\hline Regression & 4.236 & 4 & 1.059 & 1.051 & .466 \\
Residual & 5.038 & 5 & 1.008 & & \\
Total & 9.274 & 9 & & & \\
\hline
\end{tabular}

Source: SPSS Printout of Multiple Regression Computed from table 1 above

The tested hypothesis and the regression result in table 5 reveal that coefficient of POS is 2.148 , which indicate a positive relationship between ROE and POS. However, coefficient of ATM, INTERNET and MOBILE Banking are $-0.818,-0.212$ and -1.515 shows that there is no correlation between ROE and ATM, INTERNET and MOBILE Banking. Their p-value of 0.318, 0.664, 0.402 and 0.502 are more remarkable than 0.05 significant levels which indicate that it is not statistically significant. In light of this, we accept the null hypothesis by rejecting the alternative idea and conclude that electronic banking has no significant impact on return on equity. 
4.3.3 Ho3: There is no significant impact between electronic banking and earnings per share Table 8: Regression Result Computation from Table 1 above

\begin{tabular}{|c|c|c|c|c|c|}
\hline \multirow[b]{2}{*}{ Model } & \multicolumn{2}{|c|}{ Unstandardized Coefficients } & \multirow{2}{*}{$\frac{\text { Standardized Coefficients }}{\text { Beta }}$} & \multirow[b]{2}{*}{$\mathrm{T}$} & \multirow[b]{2}{*}{ Sig. } \\
\hline & $\mathrm{B}$ & Std. Error & & & \\
\hline 1 (Constant) & .118 & .051 & & 2.309 & .069 \\
\hline ATM & -.001 & .000 & -.814 & -1.066 & .335 \\
\hline INTERNET & -.009 & .021 & -.197 & -.413 & .697 \\
\hline POS & .075 & .085 & 2.137 & .881 & .419 \\
\hline MOBILE & -.032 & .044 & -1.578 & -.729 & .499 \\
\hline
\end{tabular}

Dependent Variable: EPS

Source: SPSS Printout of Multiple Regression Computed from table 1 above

Table 9: Model Summary

\begin{tabular}{|c|c|c|c|c|c|c|c|}
\hline Model & $\mathrm{R}$ & R Square & $\begin{array}{l}\text { Adjusted R } \\
\text { Square }\end{array}$ & $\begin{array}{l}\text { Std. Error of } \\
\text { the Estimate }\end{array}$ & $\begin{array}{l}\text { R Square } \\
\text { Change }\end{array}$ & F Change & $\begin{array}{l}\text { Durbin } \\
\text { Watson }\end{array}$ \\
\hline 1 & $.647^{\mathrm{a}}$ & .419 & -.045 & .09784 & .419 & .902 & .986 \\
\hline
\end{tabular}

Source: SPSS Printout of Multiple Regression Computed from table 1 above

Table 10: ANOVA

\begin{tabular}{|l|l|l|l|l|l|}
\hline Model & Sum of Squares & Df & Mean Square & F & Sig \\
\hline Regression & .035 & 4 & .009 & .902 & .527 \\
Residual & .048 & 5 & .010 & & \\
Total & .082 & 9 & & & \\
\hline
\end{tabular}

Source: SPSS Printout of Multiple Regression Computed from table 1 above

The tested hypothesis and the regression result in table 8 revealed that the coefficient of Point of Sale is 2.137, which indicate a positive relationship between EPS and POS. However, the coefficient of ATM, INTERNET and MOBILE banking are $-0.814,-0.197$ and -1.578 which is an indication of a negative relationship between EPS and ATM, INTERNET and MOBILE Banking. Their p-value of $0.335,0.697,0.419$ and 0.499 are more remarkable than 0.05 significant levels which indicate that it is not statistically significant. By this, we accept the null hypothesis and conclude that electronic banking has no significant impact on earnings per share.

\subsection{Summary of Findings}

The findings ascertained that there exists a negative association between three of the e-banking services (ATM, INTERNET and MOBILE Banking) and bank performances. At the same time, the relationship between Point of Sale and bank performance is positive. The implication is that a slight variation in the measure of adoption and investment in EB will stem into a commensurable decrease in the performance level of banks.

The Co-efficient of correlation ( $\mathrm{r}$ ) shows the extent of the correlation between the variables. The value of $0.852,0.676$ and 0.647 in table 3,6 and 9 indicates a positive relationship between the variables. This also reveals a reasonable degree of reliability between the variables.

The Co-efficient of Determination $\left(\mathrm{R}^{2}\right)$ is the portion of the variants in the dependent variable that is traceable to the variations in the independent variable. Tables 3,6 and 9 revealed that about $73 \%(0.725), 46 \%(0.457)$ and $42 \%(0.419)$ of the variations in the dependent variable are ascribed to variations in the independent variables.

The Adjusted Coefficient of Determination $\left(\mathrm{R}^{2}\right.$ Adjusted) shows the total variations in the dependent variable attributable to the independent variable. Table 3,6 and 9 above revealed that the adjusted coefficient of determination are $0.505,0.022$ and 0.045 , which indicates that the attested variation is $0.505 \%, 0.022 \%$ and $0.045 \%$ as against $73 \%, 46 \%$ and $42 \%$ suggested by regular $\mathrm{R}^{2}$. The Durbin Watson tests value of $1.390,0.988$ and 0.986 shows that serial correlation is not a challenge to the statistical validity inferences derivable from the regression result. The F-Statistics (F-ratio) is the overall significance of the model and evaluates the goodness of fit model by testing its explanatory power of the model. The model is insignificant because the p-value of $0.111,0.466$ and 0.527 is greater than $5 \%$ levels of significance.

The estimated coefficient of electronic banking services is negative. This is a clear signal that electronic banking of the deposit money banks under review do not increase ROA, ROE and EPS but somewhat decreases it insignificantly. The fact is that investment in EB services raises bank expenditure and assets while reducing operating profits. This, in turn, reduces the return on assets, return on equity and earnings per share. We, therefore, accept the null hypothesis and conclude that electronic banking decreases bank performance in Nigeria. The result also indicates that the effect is relatively insignificant as the p-value of all coefficients is $>.05$ level of significance. 
This result conforms with the findings of Becalli (2009), Mohammed (2011), Oginini et al. (2013), Onayi, Ozsoz and Helvacioglu (2008), Malhotra and Singh (2009)and Mohammad and Saad (2011).

\section{Conclusion and Recommendations \\ 5.1 Conclusion}

The liberalization of the Nigerian banking sector has brought about a positive change and a healthy competition in the Nigerian banking industry, through a computerized and improved bank service delivery.

The following conclusions are made based on the findings of this study: (i) Investment in ICT do not improve the performance of DMBs in Nigeria. The basis for this is that most of the commercial banks in Nigeria are in financial distress since consolidation. (ii) Profit serves as a driving factor for the performance of DMBs in Nigeria. However, the appropriate measure of performance is the ROA, ROE and EPS. The analysis suggests that electronic banking is negatively correlated with Bank performance signifying that electronic banking services of deposit money banks do not increase their performance, but somewhat decreases it insignificantly. This result may be because, investment in e-banking increases expenditure and also grows assets thereby causing a reduction in the operating profits as well as return on assets (ROA), return on equity (ROE) and earnings per share (EPS). Again, most of the banks invested heavily in ICT related facilities as a result of the competition that arose after the consolidation to enhance efficiency, growth and survival.

\subsection{Recommendations}

i. The efficient utilization of the ICT facilities put in place should be encouraged rather than the purchase of new ones.

ii. For effectiveness in electronic banking, there should be rigorous campaign and awareness for clients to patronize the facilities for them to reap the benefit of ICT.

iii. The Government and the various regulatory agencies must put in place proper policy measures regarding electronic banking operations as well as monitoring team to ensure compliance to attain the goal of the adoption of ICT and organizational efficiency.

\section{Bibliography}

Abaenewe, Z. C., Ogbulu, O. M. \&Ndugbu, M. O. (2013). Electronic Banking and Bank performance in Nigeria. West African Journal of Industrial Academic Researcher, 6(1); 457-567.

Agboola, A. A. (2006). Electronic Payment Systems and Tele-banking Services in Nigeria. Journal of Internet Banking and Commerce.11 (3); 201-252.

Auta, M. E. (2010): E-banking in Developing Economy: Empirical Evidence from Nigeria. Journal of Applied Quantitative Methods.5 (2); 34-56.

Ayo, C. K. (2010). The State of E-Banking Implementation in Nigeria: A Post-Consolidation Review. Journal of Emerging Trends in Economics and Management Sciences (JETMS).1(1):37-45.

Becalli, E (2009). Does IT Investment Improve Bank Performance? Evidence from Europe. Journal of Banking and Finance Vol. 31 (7), Pp 2205-2230

Central Bank of Nigeria Annual Reports (2006- 2017)

Coleman, A. \& Nicholas- Biekpe, N. (2006): Does Board and CEO Matter for Bank Performance? A Comparative Analysis of Banks in Ghana, Journal of Business Management, University of Stellenbosch Business School (USB), Cape Town, South Africa. 13(1); 46-59.

Dandapani, K., Karels, G. V., \& Lawrence, E. R. (2006). Internet Banking Services and Credit Union performance. Managerial Finance, 34(6), 437-446.

Idowu, P. A., Alu, A. O. \&Adagunodo, E.R. (2002). The Effect of Information and Communication Technology (ICT) in Nigerian Banks. Internet Banking in Nigeria: An Appraisal, Information Technology Journal.Iran. International Journal of Economics and Finance, 2(1), 201-209.

Josiah, A. \& Kingoo, N. (2012). The Relationship Between Electronic Banking and Financial Performance Among Commercial Banks in Kenya. Journal of Finance and Investment Analysis. 1(3); 99-118.

Kariuki, N. ( 2005). Six Puzzles in Electronic Money and Banking, IMF Working Paper, I" Institute.

Liao, Z. Cheung, M.T. (2002). "Internet-Base" and Consumer Attribute": An Empirical Study," Information \& Management, 39: 283-295.

Malhotra, P. \& Singh, B. (2009). The Impact of Internet Banking on Performance and Risk: The Indian Experience. Eurasian Journal of Business and Economics 2009. 2(4): 43-62.

Milind, S. (2005). The Impact of Internet Banking on Performance and Risk Profile: Evidence from Australian Credit Unions. Journal of Banking Regulations 6(2): 163-174

Mohammad, A. O \& Saad, A. A. (2011).The Impact of E-Banking on the Performance of Jordanian Banks. Journal of Internet Banking and Commerce, August 2011, 16 (http://www.arraydev.com/commerce/jibc/) 
Mohammad, O. A., Riyadh, S. A. \& Saad, A.A. (2011). The Impact of E-Banking on Performance of Jordanian Banks. Journal of Internet Banking and Commerce. 16(2); 34- 56.

Nigerian Stock Exchange Fact Books (2008 - 2017)

Oginni, S. O., Mohammad, A., El- Maude, J. G. \&Arikpo, I. A. (2013). E-Banking and Bank Performance: Evidence from Nigeria. International Journal of Scientific Engineering and Technology. 2(8); 766-771.

Onay, C., Ozsoz, E. A. \&Helvacıoglu, A. D. (2008). The Impact of Internet Banking on Bank Profitability: the Case of Turkey. Oxford Business \& Economics Conference Program

Ovia, J. (2001). Internet Banking: Practice and Potentials in Nigeria. Paper Deorganisedt a Workshop organized by ICAN at Lagos,

Rogers, E.M. (1995). Diffusion of Innovation 4th Edition.New York. The Free Press

Salawu, R.O. \& Salawu, M.K. (2007). The Emergence of Internet Banking in Nigeria: An Appraisal, Information Technology Journal. 6(4):490-496.

Salhi, M. \&Alipour, M. (2010). E-Banking in Emerging Economy: Empirical Evidence of Iran. International Journal of Economics and Finance, 2(1), 201-209.

Taylor, S. \& Todd, P.A. (1995). Understanding Information Technology Usage: A Test of Competing Models, Information Systems Research, 6(4): 144-176.

\section{APPENDIX I}

Aggregate Value of Dependent and Independent Variables

\begin{tabular}{|l|l|l|l|l|l|}
\hline YEARS & ROA & ATM & INTERNET & POS & MOBILE \\
\hline 2008 & 2.85 & 4.3 & 0.04 & 0.2 & 0.01 \\
\hline 2009 & 1.58 & 7.8 & 0.13 & 0.6 & 0.03 \\
\hline 2010 & 0.85 & 12.1 & 0.2 & 0.8 & 0.04 \\
\hline 2011 & 0.34 & 15.7 & 0.9 & 0.4 & 0.7 \\
\hline 2012 & 0.04 & 60.1 & 1.6 & 1.2 & 3.2 \\
\hline 2013 & 1.58 & 109.6 & 2.7 & 0.9 & 1.8 \\
\hline 2014 & 0.06 & 186.2 & 7.2 & 1.1 & 1.2 \\
\hline 2015 & 0.09 & 347.6 & 3.4 & 2.1 & 1.9 \\
\hline 2016 & 0.25 & 375.5 & 2.3 & 2.6 & 1.5 \\
\hline 2017 & 4.87 & 295.3 & 2.9 & 9.4 & 15.8 \\
\hline
\end{tabular}

Source: Author's Computation from Nigerian Stock Exchange Fact Book 2018

\section{APPENDIX II}

Aggregate Value of Dependent and Independent Variables

\begin{tabular}{|l|l|l|l|l|l|}
\hline YEARS & ROE & ATM & INTERNET & POS & MOBILE \\
\hline 2008 & 3.11 & 4.3 & 0.04 & 0.2 & 0.01 \\
\hline 2009 & 1.47 & 7.8 & 0.13 & 0.6 & 0.03 \\
\hline 2010 & 0.10 & 12.1 & 0.2 & 0.8 & 0.04 \\
\hline 2011 & 0.07 & 15.7 & 0.9 & 0.4 & 0.7 \\
\hline 2012 & 0.11 & 60.1 & 1.6 & 1.2 & 3.2 \\
\hline 2013 & 0.50 & 109.6 & 2.7 & 0.9 & 1.8 \\
\hline 2014 & 0.03 & 186.2 & 7.2 & 1.1 & 1.2 \\
\hline 2015 & 0.09 & 347.6 & 3.4 & 2.1 & 1.9 \\
\hline 2016 & 0.19 & 375.5 & 2.3 & 2.6 & 1.5 \\
\hline 2017 & 1.72 & 295.3 & 2.9 & 9.4 & 15.8 \\
\hline
\end{tabular}

\section{Source: Author's Computation from Nigerian Stock Exchange Fact Book 2018}




\section{APPENDIX III}

Aggregate Value of Dependent and Independent Variables

\begin{tabular}{|l|l|l|l|l|l|}
\hline YEARS & EPS & ATM & INTERNET & POS & MOBILE \\
\hline 200 & 0.26 & 4.3 & 0.04 & 0.2 & 0.01 \\
\hline 2009 & 0.23 & 7.8 & 0.13 & 0.6 & 0.03 \\
\hline 2010 & 0.07 & 12.1 & 0.2 & 0.8 & 0.04 \\
\hline 2011 & 0.005 & 15.7 & 0.9 & 0.4 & 0.7 \\
\hline 2012 & 0.01 & 60.1 & 1.6 & 1.2 & 3.2 \\
\hline 2013 & 0.09 & 109.6 & 2.7 & 0.9 & 1.8 \\
\hline 2014 & 0.009 & 186.2 & 7.2 & 1.1 & 1.2 \\
\hline 2015 & 0.011 & 347.6 & 3.4 & 2.1 & 1.9 \\
\hline 2016 & 0.03 & 375.5 & 2.3 & 2.6 & 1.5 \\
\hline 2017 & 0.15 & 295.3 & 2.9 & 9.4 & 15.8 \\
\hline
\end{tabular}

Source: Author's Computation from Nigerian Stock Exchange Fact Book 2018 